https://doi.org/10.52449/1857-4114.2021.37-1.13

CZU: 611.7:376.33

\title{
STUDY ON THE INCIDENCE OF SPINE DEVIATIONS IN HEARING DEFICIENCY STUDENTS
}

\author{
Bughirică Georgescu Magdalena ${ }^{1}$ \\ Danciu Răzvan Constantin ${ }^{2}$ \\ ${ }^{1,2}$ National University of Physical Education and Sports, Bucharest, Romania
}

\begin{abstract}
The correct posture of students is conditioned by a multitude of factors. The spine is the axis around which the other body segments are positioned for a harmonious body.

The purpose of this study is to identify the incidence of spinal deviations at students with sensory hearing impairments selected in the physical therapy program conducted in special schools in Bucharest. We wanted to find out if there are statistical differences between the two categories of subjects (with mild/moderate deficiencies and with poor/severe/deep and/or associated deficiencies) related to the incidence of deformities/deviations in the spine.

The research sample was composed of 216 students enrolled in special education in Bucharest. The criteria for forming the working groups were: hearing impairment, degree of disability, gender and level of education (primary or secondary).

Conclusions. The incidence of the disease is different in students with hearing impairments enrolled in primary and secondary education.

For students with poor/severe/profound hearing impairment, the most common condition is lordosis followed by kypholordosis and neurological disorders.
\end{abstract}

Keywords: spine, hearing disabilities, special education system.

\section{Introduction.}

Diseases of the osteo-musculoskeletal system are one of the most common pathological manifestations, both in terms of morbidity and economic costs.

Therefore, an assessment of the level of physical development and health is necessary, based on medical examinations in children in school communities. To this end, the initial assessment of students by physiotherapists, through various tests and measurements specific to physiotherapy, has a key role in detecting those with disabilities [1].

The current topic of detecting, preventing and correcting vertebral postural disorders among the school population is a current concern for both parents and teachers who grow and educate these age groups. Vertebral postural impairments are characterized by varying degrees of obvious morphological changes, which occur in the shape and structure of the body, manifested by a developmental disorder or disproportionate development, by deviations, structural deformities, followed or preceded by functional disorders [2].

Structured deformities of the spine are a problem at school age, sometimes seriously affecting the health of the future adult. The child's body is in a constant state of development, and growth is uneven, alternating periods of sudden growth with a slowdown in development [2]. According to specialized studies, more and more schooled children are detected annually with deviations from normal body posture [3]. 
In this study we intend to present the incidence of spinal deviations in students with hearing impairments selected in the physical therapy program conducted in special schools in Bucharest. In this regard, we consider it important to report an overview of the incidence of diseases that benefit from kinetic treatment in the special education system.

Special education, subordinated by the Ministry of Education and Research, is an integral part of the Romanian education system that offers all children/young people educational programs appropriate to the degree of disability and their development needs [4].

Children and young people with different types of disabilities can be enrolled, depending on the degree of disability, in the special education system or in mainstream education.

In Bucharest, 2 special schools carry out their educational activity where students with hearing impairments are educated at preschool, primary and secondary level. Classes are divided according to the degree of disability, into classes for students with mild/moderate disabilities and into classes for students with poor/severe/profound/and or associated disabilities.

Research shows that about $3 \%$ of children have hearing impairments, ranging from mild to severe. Of those affected, about $10 \%$ fall into the "severe" category [5].

According to Dr. Ilie G., "Hearing is one of the fundamental senses of man." Alteration of hearing function causes disorders in the orientation of the child in the environment, but also difficulties in communicating with peers. Hearing loss, also called deafness (or hearing loss), is not really a disease, but a symptom that can have multiple causes. The child's hearing loss may be hereditary or may occur late, after a variable period of time [6].

Hearing impairment is severe not so much by the type, form of manifestation but, especially, by the negative influences on the processes of perceiving sounds necessary for the formation and normal development of speech, language of the child's thinking. The child with hearing impairments, first of all, is characterized by speech: voice intensity, vocabulary richness, exposure, etc. The child with hearing impairment uses verbal symbols saturated with visual elements. Cognitiveverbal memory develops more slowly, while visual-motor and affective memory develops faster [7]. In order to develop practical skills and knowledge about the world around, students with hearing impairments must participate in activities / programs designed to learn the language, perception of time, familiarization with the environment [7]. Students with hearing impairments have low listening skills, so it is important that the teacher knows how to pass the information. The teacher's address to students must be clear, simple and concise. The teacher will make sure that the student has understood the task before starting the activity.

This study was made possible by the participation of special education schools in Bucharest that educate children and adolescents with hearing impairments. They wanted to be included in this study by providing the required data on: the number of students in education at the level of the institution, the type and number of diseases receiving physiotherapy following annual assessments made by school physiotherapists. Physical therapy teachers perform an assessment of all students at the beginning of each school year, called the initial assessment [8].

As we well know, physical therapy is a therapeutic branch that uses movement as a specific means, in order to recover somatofunctional, motor and psychomotor or reeducation of compensatory functions, in case of partially reversible or irreversible deficiencies. Physical therapy is indispensable for medical recovery, mental rehabilitation, vocational rehabilitation and social rehabilitation [9].

Physical therapy applied in the special school aims to recover students with various locomotor, neuro-motor disorders (at the 
central or peripheral level), grafted on hearing impairments. For this purpose, a fundamental role is played by the initial assessment of students, to detect those with deviations from normal, through numerous tests and measurements specific to physical therapy, in conjunction with the study of medical records, knowledge of socio-familial situation and socio-economic environment, from which the students come, discussions with the educational factors involved in the process of recovery / integration of the students (conversations with the school doctor, teacher, educator, psychologist, etc.). For maximum efficiency, the treatment can be individualized (by designing personalized intervention programs), by constantly reporting the type and severity of the disease, but also the type and degree of primary deficiency on which the motor disorder is grafted.

Physical therapy is also an intervention that involves training motor skills, body exercises, sensory stimulation activities and games to improve manual motor skills [10]. Thus, the kinetotherapy contributes together with the other therapeutic-recuperative disciplines, to the increase of the degree of adaptability by correcting, ameliorating and/or compensating the diseases of the locomotor system.

The aim of the study is to establish the incidence of spinal deviations in students with hearing impairments (aged 6-18 years-old) selected in the physical therapy program conducted in special schools in Bucharest.

\section{Objectives of the study}

The objectives of this study included:

1. Gathering conclusive information on spinal deformities in school children.

2. Evaluation of body attitudes in students with hearing impairments enrolled in the special education system in Bucharest [11].

3. Centralization of data on the involvement of children and young people with hearing impairments in the school's physical therapy program.

4. Comparison of the incidence of physical deficiencies of the spine in students with hearing impairments respecting the criteria of gender, level of education and degree of disability.

5. Highlighting the percentage differences in terms of physical deformities of the spine between students with mild / moderate hearing impairments on the one hand and severe / severe / profound / and or associated on the other hand.

\section{Research methodology and organization}

Materials and methods

1. Reading the specialized literature on normal and pathological body posture; characteristics of children with hearing impairments.

2. Providing tests, measurements and assessment tests to detect spinal deficiencies [12] for children with hearing impairments.

3. Detection of general or segmental deviations of the spine as a result of the assessment of body posture [13] in children with hearing impairments.

4. Creating a database with information about the existence of physical disabilities of the spine in children and adolescents with hearing impairments involved in the school's physical therapy program.

5. Establishing the number of subjects involved in the physiotherapy program at the level of special education in Bucharest, respecting the grade, gender, type of physical deficiency at the level of the spine and level of education.

6. Fixing the percentages of subjects involved in the recovery program, for each degree of disability (mild / moderate on the one hand and severe / severe / profound / and or associated degree on the other hand).

7. Data analysis, processing and interpretation.

8. Formulation of some conclusions.

\section{Research sample}

A total of 216 subjects enrolled in two schools that offer special education services for students with hearing impairments were involved in conducting this study. The group of subjects with mild / moderate degree of 
deficiency included 115 subjects and 101 subjects with poor/severe/profound/and or associated degree. We mention that the evaluation of the subjects was performed during the physiotherapy program (initial evaluation) at the beginning of the 2020-2021 school year. The group of subjects included all students with hearing impairments enrolled in the two special schools in Bucharest (Special Gymnasium School for the Deaf No. 1 and Special Gymnasium School for the Hearing Impaired No.2 (currently called the Special Vocational School for the Deaf "Saint Mary") Table 1.

Table 1. Distribution of subjects according to degree of disability and levels of education

\begin{tabular}{|c|c|c|c|c|c|}
\hline \multirow[t]{2}{*}{ Educational institution } & \multirow{2}{*}{$\begin{array}{l}\text { Total } \\
\text { enrolled } \\
\text { subjects } \\
\text { (Class } \\
\text { P-X) }\end{array}$} & \multirow{2}{*}{$\begin{array}{l}\text { Total } \\
\text { enrolled } \\
\text { subjects } \\
\text { MD }\end{array}$} & \multirow{2}{*}{$\begin{array}{l}\text { Total } \\
\text { enrolled } \\
\text { subjects } \\
\text { SD }\end{array}$} & \multicolumn{2}{|c|}{$\begin{array}{l}\text { Level of } \\
\text { education }\end{array}$} \\
\hline & & & & $\begin{array}{l}\text { Class } \\
\text { P-IV }\end{array}$ & $\begin{array}{l}\text { Class } \\
\text { V-X }\end{array}$ \\
\hline $\begin{array}{l}\text { Gymnasium School. } \\
\text { Special for the Deaf } \\
\text { No.1 }\end{array}$ & 111 & 92 & 19 & 68 & 43 \\
\hline $\begin{array}{l}\text { Special Gymnasium } \\
\text { School for the Hearing } \\
\text { Impaired No. } 2\end{array}$ & 105 & 23 & 82 & 37 & 68 \\
\hline Total & 216 & 115 & 101 & 105 & 111 \\
\hline
\end{tabular}

Abbreviations:

MD - subjects with mild/moderate degree of deficiency

MS - subjects with severe degree of deficiency

P-IV - subjects enrolled in the preparatory class - 4th grade

$\mathrm{V}-\mathrm{X}$ - subjects enrolled in the 5 th to 10 th grade

Evaluation methods. The program of activities with students with hearing impairments enrolled in the special education system is imposed by the curriculum as in the case of other students. Physiotherapy is part of the discipline program "Specific and compensatory therapies", along with psychodiagnosis, counseling, therapy of language disorders, etc.

As a subject, physical therapy is provided in the curriculum for all types and degrees of disability. Thus, classes of students with mild/moderate disabilities have one hour of physical therapy per week, and classes of students with poor/severe/profound/severe disabilities have two hours of physical therapy per week. Physiotherapy teachers evaluate all students at the beginning of each school year - initial assessment [14] after which therapy groups are established. The evaluation of the musculoskeletal system is performed - the evaluation of physical growth and development by subjective methods (somatoscopy) and by objective methods (somatoscopic instrumental examination) [13].

The evaluations are: somatometry, evaluation of grip, evaluation of gait, evaluation of joint amplitude and muscle strength, evaluation of exercise capacity. The anamnesis is also performed with students and family members, keeping information from students' medical records. If the physiotherapy teacher detects diseases of the musculoskeletal system, he directs the students to the school doctor or to the specialist doctor to confirm the diagnosis. 
Table 2. Distribution of subjects with hearing disabilities involved in physiotherapy activities in the special education system in Bucharest

\begin{tabular}{|l|l|l|l|}
\hline \multicolumn{1}{|c|}{ Educational institution } & \multicolumn{1}{|c|}{$\begin{array}{c}\text { Enrolled } \\
\text { students }\end{array}$} & $\begin{array}{l}\text { No. of kinesio } \\
\text { therapy lesons }\end{array}$ & $\begin{array}{l}\text { No. of involved } \\
\text { students }\end{array}$ \\
\hline $\begin{array}{l}\text { Gymnasium School. Special for } \\
\text { the Deaf No.1 }\end{array}$ & 111 & 23 & 46 \\
\hline $\begin{array}{l}\text { Special Gymnasium School } \\
\text { for the Hearing Impaired No. 2 }\end{array}$ & 105 & 26 & 78 \\
\hline Total & $\mathbf{2 1 6}$ & $\mathbf{4 9}$ & $\mathbf{1 2 4}$ \\
\hline
\end{tabular}

\section{Results and discussions}

The data presented in this study were centralized following evaluations performed on students by special school physiotherapists included in the study.

We present the main deviations of the spine encountered in students with hearing impairments depending on gender, level of education and degree of disability (Table 3 ).

We can observe from the data entered in table 2 that those 124 students with hearing disabilities are involved in a number of 49 physiotherapy activities. From this we can deduce that, on average, the working groups are made up of 2.53 students per activity.

The conduct and organization of the physiotherapy program are different in terms of the number of students in a working group, depending on the type and degree of disability. The 216 enrolled subjects, 124 (57\%) were diagnosed with various diseases that benefit from physical therapy.

The highest incidence of the total detected diseases is represented by the deviations of the spine 99 subjects $(45.83 \%)$ (Table 3 ).

Table 3. Number of subjects involved in the physiotherapy program by degree of disability, gender, level of education and type of disease

\begin{tabular}{|c|c|c|c|c|c|c|c|c|c|c|}
\hline \multirow[t]{4}{*}{ Type of deficiency } & \multirow{2}{*}{\multicolumn{4}{|c|}{$\begin{array}{c}\text { MD } \\
\text { School level }\end{array}$}} & \multirow{4}{*}{ 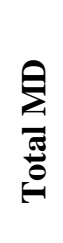 } & \multirow{2}{*}{\multicolumn{4}{|c|}{$\begin{array}{c}\text { SD } \\
\text { School level }\end{array}$}} & \multirow{4}{*}{ 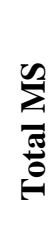 } \\
\hline & & & & & & & & & & \\
\hline & \multicolumn{2}{|c|}{$\begin{array}{l}\text { Class } \\
\text { P-IV }\end{array}$} & \multicolumn{2}{|c|}{$\begin{array}{l}\text { Class } \\
\text { V-X }\end{array}$} & & \multicolumn{2}{|c|}{$\begin{array}{l}\text { Class } \\
\text { P-IV }\end{array}$} & \multicolumn{2}{|c|}{$\begin{array}{l}\text { Class } \\
\text { V-X }\end{array}$} & \\
\hline & $\mathrm{M}$ & $\mathrm{F}$ & M & $\mathrm{F}$ & & $\mathrm{M}$ & $\mathrm{F}$ & $\mathrm{M}$ & $\mathrm{F}$ & \\
\hline Kyphosis & 2 & 1 & 1 & 2 & 6 & 1 & - & 3 & 3 & 7 \\
\hline Lordosis & 2 & 1 & 2 & 3 & 8 & 6 & 7 & 14 & 14 & 41 \\
\hline Kypho-lordosis & 1 & 1 & 4 & 1 & 7 & 2 & 1 & 4 & 8 & 15 \\
\hline Scoliosis C & 1 & 1 & 1 & 1 & 4 & 1 & - & 4 & 3 & 8 \\
\hline Scoliosis S & - & - & - & - & - & - & - & 1 & 1 & 2 \\
\hline Kypho- scoliosis & - & - & 1 & - & 1 & - & - & 1 & 1 & 2 \\
\hline Neurological diseases & - & - & - & - & - & 3 & & 6 & & 9 \\
\hline Other diseases & & & & & 2 & 5 & & 7 & & 14 \\
\hline
\end{tabular}

Abbreviations:

MD - subjects with mild/moderate degree of deficiency

MS - subjects with severe degree of deficiency

P-IV - subjects enrolled in the preparatory class - 4th grade

$\mathrm{V}-\mathrm{X}$ - subjects enrolled in the 5th to 10 th grade 
Analyzing the data contained in Table 3 we can see that out of the 124 subjects included in the physiotherapy program 99 subjects $(79.83 \%)$ were detected with deviations of the spine, 9 subjects $(7.25 \%)$ were detected with neurological disorders and 16 subjects $(12.90 \%)$ have other conditions.

The most common deformities in the spine that benefit from physiotherapy in the order of percentage are: lordosis, kypholordosis, kyphosis, scoliosis C, scoliosis S and kyphoscoliosis.

Considering that the two groups of subjects involved in the study (subjects with mild/moderate degree and subjects with poor/severe/profound degree/or associated on the other hand) do not consist of an equal number of students, we consider it necessary to transform the number of students with a certain diagnosis into percentages, compared to the total number in that category (Table 4)

Table 4. Incidence of diagnoses in school subjects

\begin{tabular}{|c|c|c|}
\hline \multirow{2}{*}{ The type of disease } & \multicolumn{2}{|c|}{ Degree of disability } \\
\cline { 2 - 3 } & TOTAL MD & TOTAL SD \\
\hline Kyphosis & $5,21 \%$ & $6,93 \%$ \\
\hline Lordosis & $6,95 \%$ & $40,59 \%$ \\
\hline Kypho-lordosis & $6,08 \%$ & $14,85 \%$ \\
\hline Scoliosis C & $3,47 \%$ & $7,92 \%$ \\
\hline Scoliosis S & - & $1,98 \%$ \\
\hline Kypho- scoliosis & $0,68 \%$ & $1,98 \%$ \\
\hline Neurological diseases & - & $8,21 \%$ \\
\hline Other diseases & $1,73 \%$ & $13,86 \%$ \\
\hline
\end{tabular}

Of the total spinal deformities, the most common condition is lordosis 49 cases $(49.49 \%)$ with very small differences between males (24 cases) and females (25 cases), kypholordosis 22 cases $(22.22 \%)$, without gender differences. With kyphosis were detected 13 cases (13.13\%) with differences of 1 subject between males and females, scoliosis in C 12 cases $(12.12 \%)$ with a higher percentage in males and with scoliosis in $\mathrm{S} 2$ cases $(2.02 \%)$.

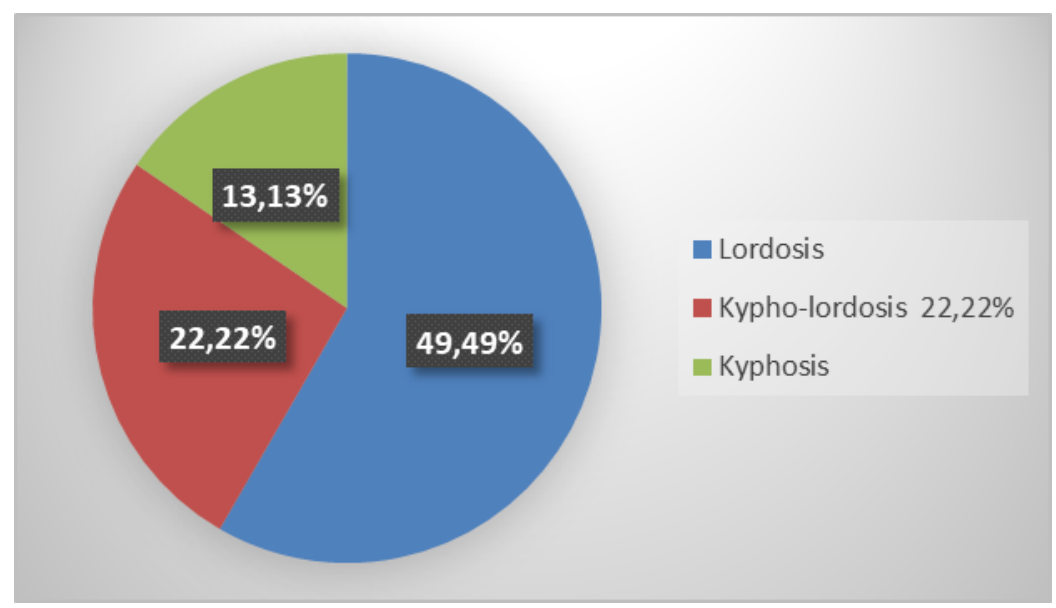

Fig. 1. The first three conditions encountered in students with hearing impairments 


\section{Conclusions:}

1. Out of the total number of subjects $(216$ students enrolled at primary and secondary level), 124 subjects $(57 \%)$ were involved in the physiotherapy program.

2. The incidence of diseases is different in students with sensory hearing impairments enrolled in primary and secondary education depending on the degree of disability. For students with poor/severe/profound sensory impairment, the most common condition is lordosis followed by kypholordosis and neurological disorders. For students with mild / moderate hearing impairment, the first three conditions found are: lordosis followed by kypholordosis and kyphosis.

3. The most common deviation of the spine for students with hearing impairments is attitudinal and structural lordosis.

4. Refering to gender, a significant difference occurs in the case of kypholordosis - more boys (mild/moderate hearing impairment) detected and more girls (poor/severe/profound hearing impairment) detected.

5. This study is the first step in deepening the knowledge of the incidence of diseases in students with disabilities in the special education system.

\section{References:}

1. Lafond D., Descarreaux M., Normand M.C. \& Harrison D. E. (2007). Postural development in school children: a cross-sectional study. Chiropractic \& Manual Therapies, 15, 1. https://doi.org/10.1186/1746-1340-15-1

2._Bughirică-Georgescu M. (2021). The Incidence of Vertebral Static Disorders at Children Aged 11-14 Years. BRAIN. Broad Research in Artificial Intelligence and Neuroscience, 11(4 Sup. 1), p. 30-45. https://doi.org/10.18662/brain/11.4Sup1/154

3. Ciovică C., Voinea C., Opran T., Săpoi V., Kamal D. \& Trăistaru R. ( 2016). Importanța evaluării aliniamentului postural la școlari. Revista de Medicină Școlară și Universitară, III (4), p.5-10.

4. Politicile Educaţionale pentru elevii în situaţie de risc şi pentru cei cu dizabilităţi, pag. 7. https://www.oecd.org/countries/romania/38614298.pdf

5. http://www.educationcorner.com/strategies-for-hearing-impaired-students.html

6. Ilie G. Centrul Medical de Diagnostic si Tratament, Dr. Victor Babes. https://www.cdtbabes.ro/articole/handicap_auz.php

7. Brașoveanu E. (2003). Copilul cu deficiențe de auz și școala de cultură generală. Centrul Educaţional PRO DIDACTICA, Republica Moldova, p.36-37.

8. Horvat M., Block M.E., Kelly L.E. (2007). Developmental and Adapted Physical Activity Assessment. Human Kinetics, p.137-157.

9. Cordun M. (1999). Kinetologie Medicală. București: Editura Axa. 438 p.

10.Danciu R.C., Marinescu G., Ticală L.D. (2019). Challenging autism with physical therapy. În Ovidius University Annals, Series Physical Education and Sport / SCIENCE, MOVEMENT AND HEALTH Vol. XIX, ISSUE 2 Supplement, pag. 214. Romania, Constanţa.

11.Antonescu D., Obraşcu C., Ovezea A. (1993). Corectarea coloanei vertebrale. București: Editura Medicală. 220 p.

12. Jianu M. (2009). Noțiuni practice de ortopedie pediatrică de la nou-născut la adolescent. București: Pro Editură şi Tipografie, p. 55-71.

13.Cordun M. (1999). Postura corporală normală şi patologică. București. Editura ANEFS, p. 92-152.

14.Horvat M., Block M.E., Kelly L.E. (2007). Developmental and Adapted Physical Activity Assessment. Human Kinetics, p. 137-157. 